\title{
Enoxacin elevates microRNA levels in rat frontal cortex and prevents learned helplessness
}

\author{
Neil R. Smalheiser ${ }^{1}$, Hui Zhang ${ }^{1}$ and Yogesh Dwivedi ${ }^{2}{ }^{*}$ \\ 1 Department of Psychiatry, Psychiatric Institute, University of Illinois at Chicago, Chicago, IL, USA \\ ${ }^{2}$ Department of Psychiatry and Behavioral Neurobiology, University of Alabama at Birmingham, Birmingham, AL, USA
}

\section{Edited by:}

Don A. Baldwin, Pathonomics, LLC, USA

\section{Reviewed by:}

Farah D. Lubin, University of Alabama at Birmingham, USA

Khyobeni Mozhui, University of Tennessee Health Science Center, USA

\section{*Correspondence:}

Yogesh Dwivedi, UAB Mood Disorder Program, Department of Psychiatry and Behavioral Neurobiology, University of Alabama at Birmingham, SC711 Sparks Center, 1720 2nd Avenue South, Birmingham, AL 35294-0017, USA

e-mail: ydwivedi@uab.edu
Major depressive disorder (MDD) is a major public health concern. Despite tremendous advancement, the pathogenic mechanisms associated with MDD are still unclear. Moreover, a significant number of MDD subjects do not respond to the currently available medication. MicroRNAs (miRNAs) are a class of small non-coding RNAs that control gene expression by modulating translation, mRNA degradation or stability of mRNA targets. The role of miRNAs in disease pathophysiology is emerging rapidly. Recently, we reported that miRNA expression is down-regulated in frontal cortex of depressed suicide subjects, and that rats exposed to repeated inescapable shock show differential miRNA changes depending on whether they exhibited normal adaptive responses or learned helpless (LH) behavior. Enoxacin, a fluoroquinolone used clinically as an anti-bacterial compound, enhances the production of miRNAs in vitro and in peripheral tissues in vivo, but has not yet been tested as an experimental tool to study the relation of miRNA expression to neural functions or behavior. Treatment of rats with 10 or $25 \mathrm{mg} / \mathrm{kg}$ enoxacin for 1 week increased the expression of miRNAs in frontal cortex and decreased the proportion of rats exhibiting $\mathrm{LH}$ behavior following inescapable shock. Further studies are warranted to learn whether enoxacin may ameliorate depressive behavior in other rodent paradigms and in human clinical situations, and if so whether its mechanism is due to upregulation of miRNAs.

Keywords: miRNAs, depression, enoxacin, behavior, rat

\section{INTRODUCTION}

Major depressive disorder (MDD) is one of the most prevalent psychiatric disorders. It affects about $17 \%$ of Americans during their lifetime (1) and is associated with psychosocial impairment, poor quality of life, significant disability (2), morbidity, and mortality $(3-5)$. MDD is being diagnosed at early ages, and about $25 \%$ of people diagnosed with MDD are below 19 years. Although much work has been done to characterize MDD, about $40 \%$ of MDD patients do not respond to the currently available medications (6). This is partially a result of poor understanding of the molecular pathophysiology underlying MDD.

Compromised neural and structural plasticity has consistently been associated with MDD (7). The cellular mechanisms that underlie such compromised neural plasticity and structural impairments in MDD are not clearly understood and no single mechanism appears to be responsible for MDD etiopathogenesis; however, it is becoming increasingly evident that MDD may result from disruptions across whole cellular networks, leading to aberrant information processing in the circuits that regulate mood, cognition, and neurovegetative functions (7). In fact, evidence demonstrating impaired cellular networks that regulate neural plasticity has reshaped our views about the neurobiological underpinnings of MDD (8).

In recent years, the emergence of small non-coding RNAs as coordinated regulators of gene expression that target families of RNA sequences has gained much attention in neuropsychiatric disease pathophysiology (9). These small non-coding RNAs regulate gene expression by several mechanisms including ribosomal RNA modifications, repression of mRNA expression by RNA interference, alternative splicing, and regulatory mechanisms mediated by RNA-RNA interactions. Small non-coding RNAs include microRNAs (miRNAs), small nucleolar RNAs, small interfering RNAs, piwi-interacting RNAs, spliceosomal RNAs, and p/MRP genes. Among them, miRNAs are the most studied and well characterized and have emerged as major regulators of neural plasticity and higher brain functioning (10).

The relation between miRNA expression and depressive behavior is not straightforward. On the one hand, we recently reported that there is a global down-regulation of miRNA expression in prefrontal cortex of depressed suicide subjects (11), and have replicated this finding in an additional cohort (12). On the other hand, when rats were exposed to repeated inescapable shock, those which adapted normally [non-learned helpless (NLH) rats] showed strong down-regulation of a specific miRNA module whereas those which exhibited learned helpless behavior (LH rats) had a blunted miRNA response (13).

In order to investigate further the relation between miRNA expression and any type of behavior, it is desirable to have an experimental tool to manipulate miRNA levels directly and independently. Enoxacin is a fluoroquinolone antibiotic that (among other actions) binds HIV-1 TAR RNA binding protein (TRBP), stabilizing the dicer-TRBP complex and raising miRNA levels 
globally (14-16). Although enoxacin passes the blood-brain barrier sufficiently to exert anti-bacterial effects in meningitis (17), it is not known whether enoxacin, administered peripherally in usual therapeutic doses, will have effects on miRNA levels in brain. Thus, the present study aims to examine whether enoxacin increases expression of selected miRNAs, which are enriched in brain and are involved in synaptic plasticity and neurogenesis (9). We also tested whether enoxacin is able to produce anti-depressant effects in a standard rodent paradigm, learned helplessness following inescapable shock (18).

\section{MATERIALS AND METHODS ANIMALS}

Virus-free male Holtzman (Sprague-Dawley) rats (Harlan Laboratories, Inc., Indianapolis, IN, USA) were housed in individual cages under standard laboratory conditions (temperature $21 \pm 1^{\circ} \mathrm{C}$, humidity $55 \pm 5 \%$, 12-h light/dark cycle). Animals were provided free access to food and water. Animals were housed for 3 weeks before the experiment, and the body weight was 325-350 g (1112 weeks of age) at the start of the experiment. All the experiments were performed between 8 and -10 a.m.

\section{ENOXACIN TREATMENT \\ Experiment 1}

Enoxacin treatment is described in Figure 1. Rats were given saline, 10 or $25 \mathrm{mg} / \mathrm{kg}$ enoxacin (EMD Millipore Corporation, Billerica, MA, USA catalog no. 557305) intraperitoneally (i.p.), once daily for 8 days ( $n=12-14$ in each group). Rats were decapitated $1 \mathrm{~h}$ after the last dose (Figure 1).

\section{Experiment 2}

To test whether enoxacin prevents depressive behavior, 10 rats were treated with saline, 8 rats were treated with $10 \mathrm{mg} / \mathrm{kg}$ of enoxacin, and 8 rats were treated with $25 \mathrm{mg} / \mathrm{kg}$ enoxacin for 6 days prior to subjecting animals to inescapable shock (day 6) and assessing for learned helplessness in the escape latency test (day 7). Animals were treated with enoxacin $1 \mathrm{~h}$ prior to inescapable shock (day 6) and escape latency test (day 7). The enoxacin treatment continued on days 7 and 8 (Figure 1). Induction of LH behavior is described in our earlier publication (18). Briefly, rats were placed in Plexiglass tubes and shocks were delivered by means of a computer-controlled constant current shock generator to electrodes augmented with electrode paste to the rat's tail. The inescapable shock consisted of 100 random shocks delivered for $5 \mathrm{~s}$ at the rate of $1.0 \mathrm{~mA}$, with a mean interval of $60 \mathrm{~s}$. Another sham group (four treated with saline, four treated with enoxacin $10 \mathrm{mg} / \mathrm{kg}$, and four treated with enoxacin $25 \mathrm{mg} / \mathrm{kg}$ ) was placed in Plexiglass tubes but was not subjected to shocks. The depressive behavior was tested in a shuttle box as described earlier (18). Footshock was delivered through the grid floor by a shock generator. The shuttle escape testing began with five trials (FR-1) during which a single crossing would terminate the shocks. This was followed by 25 trials (FR-2) in which a rat had to cross from one side of the shuttle box to the other and come back to terminate the shocks. Shocks were terminated automatically after $30 \mathrm{~s}$ if there was no response within that time. The intensity of the shocks was $0.6 \mathrm{~mA}$. The shocks were presented on a variable schedule. There was a 5min interval between FR-1 and FR-2. Shuttle escape latencies were recorded automatically by a computer attached to the generator and shuttle box.

Rats were divided into two groups based on the mean latency observed after FR-2: (1) those rats in which the mean latency was $\geq 20$ s (termed LH) and (2) those in which the mean latency was $<20$ s (termed as NLH). The mean latency $\geq 20$ s cut-off was chosen based on the previous studies showing that this escape latency is reliable in determining the $\mathrm{LH}$ behavior (19). In our study, we found that about $50-60 \%$ of rats showed LH behavior. This is consistent with our previous studies $(9,13,20-23)$. The rats that were confined to Plexiglass tubes and were not shocked were also tested and termed as sham rats. Rats were decapitated $24 \mathrm{~h}$ after the last escape testing.

\section{MIRNA EXPRESSION}

Total RNA was isolated in samples of frontal cortex using a modified protocol designed to optimize recovery of small RNAs (11, 24). Total RNA was isolated with Trizol reagent (Invitrogen Life Technologies, USA) according to the manufacturer's directions. GlycoBlue $20 \mu \mathrm{g}$ (Ambion) was added to the RNA precipitation step, which was allowed to proceed overnight at $-20^{\circ} \mathrm{C}$. The RNA pellet was centrifuged at $20,000 \times g$ for $25 \mathrm{~min}$ at $4^{\circ} \mathrm{C}$, rinsed with $80 \%$ ethanol in DEPC-treated water (Invitrogen Life Technologies, Carlsbad, CA, USA), resuspended and treated with RNAsecure (Ambion, Grand Island, NY, USA), and treated with DNase I using DNA-free TURBO kit (Ambion, Grand Island, NY, USA). RNA was treated with DNAse I and checked for purity by OD 260:280 ratio (NanoDrop 1000 Spectrophotometer, Thermo Scientific, Wilmington, DE, USA).

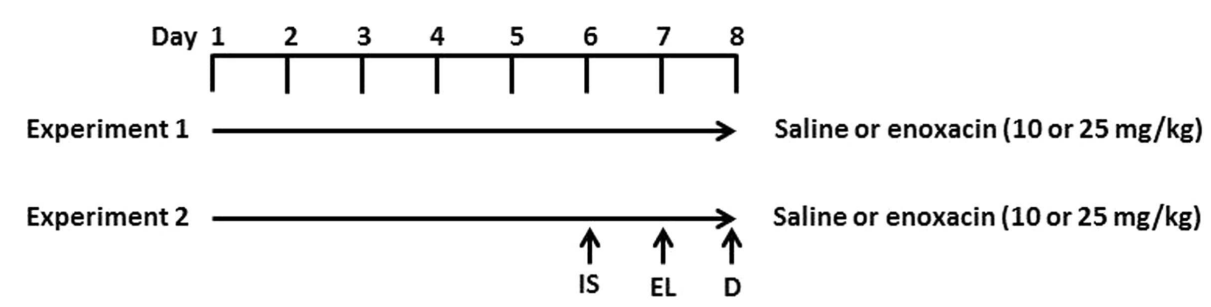

FIGURE 1 | Experimental design. In experiment 1, rats were given i.p. injections of enoxacin ( 10 or $25 \mathrm{mg} / \mathrm{kg}$ ) or saline for 8 days. One hour after the last enoxacin injection on day 8 , rats were decapitated (D). In experiment 2, rats were given i.p. injections of enoxacin
(10 or $25 \mathrm{mg} / \mathrm{kg}$ ) or saline for 8 days. On the sixth day, rats were given inescapable shock (IS) and tested for escape latency (EL) on day 7. One hour after the last enoxacin injection on day 8 , rats were decapitated. 
Expression levels of four selected miRNAs (mir-124, mir-125a, mir-132, and let-7a) were measured in the frontal cortex by realtime PCR using TaqMan primers and probes as described earlier $(11,24)$.

Briefly, $1 \mu \mathrm{g}$ of total RNA was reverse transcribed using $50 \mathrm{ng}$ random hexamers, $2 \mathrm{mM}$ dNTP mix, $10 \mu \mathrm{m}$ ribonuclease inhibitor, and $200 \mu \mathrm{m}$ MMLV-reverse transcriptase enzyme in a final reaction volume of $20 \mu \mathrm{l}$. The primer/probe sets for all target genes and endogenous controls were obtained from Applied Biosystems (Foster City, CA, USA) as the TaqMan Gene Expression Assay kit. To determine the linear range and sensitivity of the kits, a standard curve was generated using serial 10-fold dilutions. Only PCR reactions showing efficiencies above 95\% were considered acceptable. All miRNAs tested had efficiencies similar to the endogenous controls and were run in parallel with the endogenous controls. The PCR reaction was carried out in a final volume of $20 \mu \mathrm{l}$, containing $5 \mu \mathrm{l}$ of cDNA diluted 1:10 with DEPC water, $1 \times$ of TaqMan primer/probe mix $(20 \times)$, and $1 \times \operatorname{TaqMan}^{\circledR}$ Universal PCR Master Mix (Applied Biosystems, Foster City, CA, USA). For each primer/probe tested, the PCR reaction also included a non-reverse transcription negative control to confirm the absence of genomic DNA, and a non-template negative control to check for primer-dimer. All experiments were performed in duplicate as follows: denaturation at $95^{\circ} \mathrm{C}$ for $10 \mathrm{~min}$ followed by 40 cycles of a two-step program [denaturation at $95^{\circ} \mathrm{C}$ for $15 \mathrm{~s}$ and annealing/extension at $60^{\circ} \mathrm{C}$ for $1 \mathrm{~min}$ on the Mx3005p (Agilent Technologies, Santa Clara, CA, USA). All samples were run on a $2 \%$ agarose gel to confirm specificity. The amounts of target genes expressed were normalized to GAPDH and showed no significant variation in our sample set, Table 2]. Fold changes between groups were measured using the $2^{-\Delta \Delta \mathrm{Ct}}$ method, where $\Delta \Delta C_{\mathrm{T}}=\left(C_{\mathrm{T} \text { target }}-C_{\mathrm{T} \text { normalizer }}\right)_{\text {sample }}-$ $\left(C_{\mathrm{T} \text { target }}-C_{\mathrm{T} \text { endogenous gene }}\right)_{\text {control }}$.

\section{RESULTS}

As shown in Table 1, enoxacin $(10 \mathrm{mg} / \mathrm{kg})$ increased miRNA abundance levels of the selected miRNAs by 3 - to 12 -fold, and $25 \mathrm{mg} / \mathrm{kg}$ pretreatment increased miRNA levels by 4 - to 22 -fold above the levels observed in saline-treated rats. This demonstrates that "usual" therapeutic doses of enoxacin are quite effective in raising miRNA levels in the cortical area of the brain in a dose-dependent manner.

When rats were pretreated with enoxacin and subjected to inescapable shock, the LH phenotype was suppressed at both doses (Table 2). Mean escape latency for the saline group was $19.16 \mathrm{~s}$, whereas for the $10 \mathrm{mg} / \mathrm{kg}$ group, it was $9.85 \mathrm{~s}$, and for $25 \mathrm{mg} / \mathrm{kg}$, it was $7.73 \mathrm{~s}$. Non-parametric statistics (two-tailed Mann-Whitney $U$ test) showed statistically significant differences between groups: saline vs. $10 \mathrm{mg} / \mathrm{kg}, p=0.0409$; saline vs. $25 \mathrm{mg} / \mathrm{kg}, p=0.0505$; and saline vs. combined enoxacin group, $p=0.0177$.

We repeated the enoxacin effects on behavioral outcome for a second time. The rats were treated with enoxacin $(10$ or $25 \mathrm{mg} / \mathrm{kg}$ doses) for 8 days as discussed in experiment 2. A total of 26 rats were examined ( $n=8$ for sham saline-treated rats, $n=9$ for $10 \mathrm{mg} / \mathrm{kg}$ enoxacin, and $n=9$ for $25 \mathrm{mg} / \mathrm{kg}$ enoxacin). We found that enoxacin produced similar results as in Table 1 such that only two animals out of nine showed LH behavior at $10 \mathrm{mg} / \mathrm{kg}$

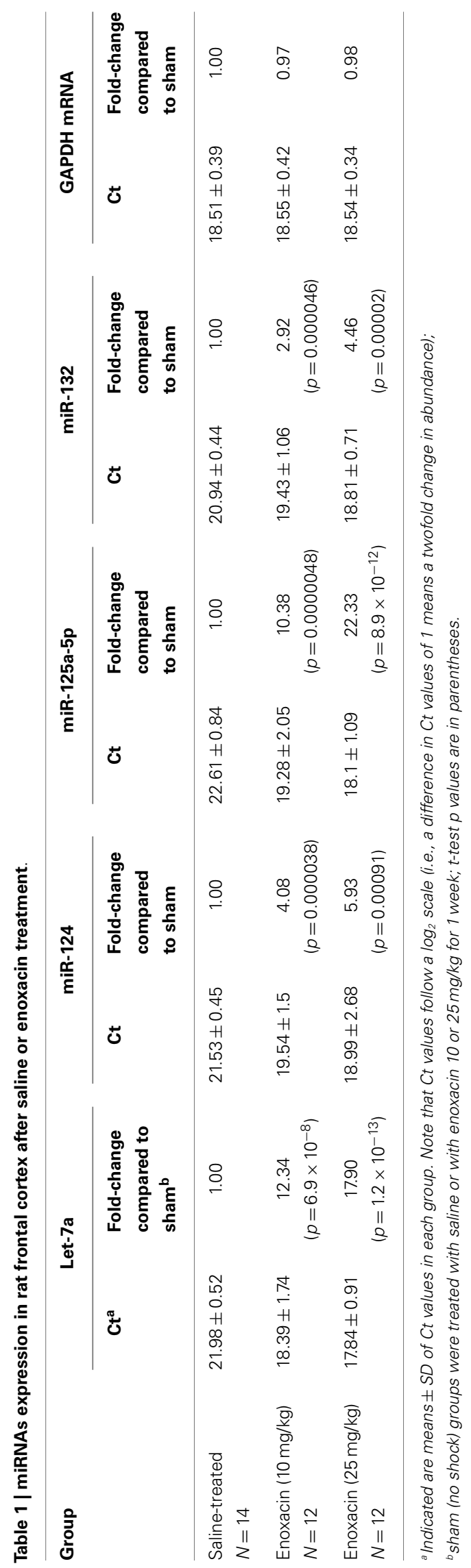


Table 2 | Escape latency of individual rats when given no shock or inescapable shock and simultaneously treated with saline or enoxacin (10 or $25 \mathrm{mg} / \mathrm{kg}$ ).

\begin{tabular}{|c|c|c|c|c|c|c|c|c|c|}
\hline & Treatment & $\begin{array}{l}\text { Escape } \\
\text { latency (s) }\end{array}$ & $\begin{array}{l}\text { Response } \\
\text { to shock }\end{array}$ & $\begin{array}{l}\text { Enoxacin } \\
\text { (mg/kg) }\end{array}$ & $\begin{array}{l}\text { Escape } \\
\text { latency (s) }\end{array}$ & $\begin{array}{l}\text { Response } \\
\text { to shock }\end{array}$ & $\begin{array}{l}\text { Enoxacin } \\
\text { (mg/kg) }\end{array}$ & $\begin{array}{l}\text { Escape } \\
\text { latency (s) }\end{array}$ & $\begin{array}{l}\text { Response } \\
\text { to shock }\end{array}$ \\
\hline Sham (no shock) & Saline & 3.27 & & 10 & 2.76 & & 25 & 4.22 & \\
\hline Sham (no shock) & Saline & 4.41 & & 10 & 3.15 & & 25 & 3.29 & \\
\hline Sham (no shock) & Saline & 4.63 & & 10 & 5.22 & & 25 & 4.37 & \\
\hline Sham (no shock) & Saline & 2.68 & & 10 & 3.17 & & 25 & 5.82 & \\
\hline Shock & Saline & 26.13 & $\mathrm{LH}$ & 10 & 21.36 & $\mathrm{LH}$ & 25 & 17.19 & $\mathrm{NLH}$ \\
\hline Shock & Saline & 26.53 & $\mathrm{LH}$ & 10 & 23.78 & $\mathrm{LH}$ & 25 & 3.91 & $\mathrm{NLH}$ \\
\hline Shock & Saline & 27.15 & $\mathrm{LH}$ & 10 & 8.62 & $\mathrm{NLH}$ & 25 & 8.66 & $\mathrm{NLH}$ \\
\hline Shock & Saline & 30.46 & $\mathrm{LH}$ & 10 & 4.47 & $\mathrm{NLH}$ & 25 & 2.83 & $\mathrm{NLH}$ \\
\hline Shock & Saline & 28.22 & $\mathrm{LH}$ & 10 & 1.68 & $\mathrm{NLH}$ & 25 & 3.96 & $\mathrm{NLH}$ \\
\hline Shock & Saline & 27.34 & $\mathrm{LH}$ & 10 & 12.27 & $\mathrm{NLH}$ & 25 & 5.32 & $\mathrm{NLH}$ \\
\hline Shock & Saline & 11.9 & $\mathrm{NLH}$ & 10 & 2.78 & $\mathrm{NLH}$ & 25 & 7.14 & $\mathrm{NLH}$ \\
\hline Shock & Saline & 3.9 & $\mathrm{NLH}$ & 10 & 3.82 & $\mathrm{NLH}$ & 25 & 12.86 & $\mathrm{NLH}$ \\
\hline Shock & Saline & 6.18 & $\mathrm{NLH}$ & & & & & & \\
\hline Shock & Saline & 4.19 & $\mathrm{NLH}$ & & & & & & \\
\hline
\end{tabular}

For rats exposed to shock, escape latency $<20 s=$ non-learned helpless (NLH); $\geq 20 \mathrm{~s}=$ learned helpless $(L H)$. As a baseline control, sham rats were given no shock on day 6 but were tested for escape latency on day 7.

enoxacin and two animals out of nine showed LH behavior at $25 \mathrm{mg} / \mathrm{kg}$ (Table A1 in Appendix).

\section{DISCUSSION}

Enoxacin belongs to a family of synthetic anti-bacterial compounds, the fluoroquinolones, which function as bacterial type II topoisomerase inhibitors (25). Shan et al. (14) showed that enoxacin and some of its analogs promote the biogenesis of endogenous miRNAs in mammalian cells by binding to TRBP, stabilizing the complex between dicer and TRBP, and enhancing dicer-mediated precursor processing and/or loading onto RNA silencing complex (RISCs). This is further confirmed by a recent study, which shows that enoxacin enhances the production of miRNAs with tumor suppressor functions by binding to the miRNA biosynthesis protein TRBP2 (15).

In the present study, we examined the effect of enoxacin on the expression of select miRNAs. These include: let-7a, miR-124, miR-125a-5p, and miR-132. Although we expect that enoxacin will increase the expression of miRNAs globally, these miRNAs were chosen because of their importance in neuronal cell biology. miR124 is involved in neurogenesis and is associated with the differentiation status of neuronal cells in mouse brain (26). By targeting glypican-4, miR-125 regulates cell growth (27). MicroRNA-125 also promotes neuronal differentiation in human cells by repressing multiple targets (28) and in mammalian neurons, miR-125 is associated with regulation of dendritic spine length (29). Let-7 is involved in neurogenesis (30) as well as neuronal development and function (31). BDNF regulates protein synthesis via let-7. BDNF stimulation upregulates Lin28, an RNA binding protein that can bind precursors of let-7, preventing them from being processed by the Dicer-TRBP machinery. The resulting diminished levels of mature let-7 miRNAs relieve repression of mRNAs with let7 binding sites and permit their translation (32). In addition, let-7 regulates dendritic spine density along the length of neurons (33). Expression of miR-132 enhances neurite outgrowth, dendritic morphogenesis, and spine formation (34-37), and is induced by BDNF via CREB. It has been shown that CREB- and activityregulated miR-132 is necessary and sufficient for hippocampal spine formation. Expression of the miR-132 target, p250GAP, is inversely correlated with miR-132 levels and spinogenesis. Furthermore, knockdown of p250GAP increases spine formation while introduction of a p250GAP mutant unresponsive to miR132 attenuates this activity. Inhibition of miR-132 decreases both mEPSC frequency and the number of GluR1-positive spines, while knockdown of p250GAP has the opposite effect. Additionally, miR-132/p250GAP circuit regulates Rac1 activity and spine formation by modulating synapse-specific Kalirin7-Rac1 signaling. These results suggest that neuronal activity regulates spine formation, in part, by increasing miR-132 transcription, which in turn activates a Rac1-Pak actin remodeling pathway. All of these miRNAs are processed by dicer and, in other systems, have been shown to respond to enoxacin (14-16).

To our knowledge, the present report is the first report to show that enoxacin increases expression of miRNAs in brain and that enoxacin affects behavioral responses of any kind. Furthermore, enoxacin given at doses within the usual anti-bacterial therapeutic range suppressed learned helplessness in rats, a standard model of depressive behavior. Further work is needed to learn the exact mechanism by which enoxacin prevented LH behavior, and whether lower doses of enoxacin that produce more modest changes in miRNA expression will also be behaviorally significant. It will also be interesting to test enoxacin in other types of behavior and in other models of depression and post-traumatic disorder. For example, using a repeated $\mathrm{LH}$ paradigm that produces a prolonged depressive phenotype (18), one may be able to learn whether enoxacin treatment can reverse learned helplessness 
after it has already been established. Enoxacin (and some of its fluoroquinolone analogs that also have effects on miRNA levels) is FDA-approved and widely used, making it an attractive reagent for study as way to modulate miRNAs in animals, and as a possible new therapeutic approach to human neuropsychiatric diseases.

\section{REFERENCES}

1. Kessler RC, McGonagle KA, Zhao S, Nelson CB, Hughes M, Eshleman S, et al. Lifetime and 12-month prevalence of DSM-III-R psychiatric disorders in the United States. Results from the National Comorbidity Survey. Arch Gen Psychiatry (1994) 51:8-19. doi:10.1001/archpsyc.1994.03950010008002

2. Broadhead WE, Blazer DG, George LK, Tse CK. Depression, disability days, and days lost from work in a prospective epidemiologic survey. JAMA (1990) 264:2524-8. doi:10.1001/jama.1990.03450190056028

3. Innamorati M, Pompili M, Gonda X, Amore M, Serafini G, Niolu C, et al. Psychometric properties of the Gotland scale for depression in Italian psychiatric inpatients and its utility in the prediction of suicide risk. J Affect Disord (2011) 132:99-103. doi:10.1016/j.jad.2011.02.003

4. Pompili M, Innamorati M, Rihmer Z, Gonda X, Serafini G, Akiskal H, et al. Cyclothymic-depressive-anxious temperament pattern is related to suicide risk in 346 patients with major mood disorders. J Affect Disord (2012) 136:405-11. doi:10.1016/j.jad.2011.11.011

5. Serafini G, Pompili M, Innamorati M, Fusar-Poli P, Akiskal HS, Rihmer Z, et al. Affective temperamental profiles are associated with white matter hyperintensity and suicidal risk in patients with mood disorders. J Affect Disord (2011) 129:47-55. doi:10.1016/j.jad.2010.07.020

6. Fava M, Davidson KG. Definition and epidemiology of treatment-resistant depression. Psychiatr Clin North Am (1996) 19:179-200. doi:10.1016/S0193953X(05)70283-5

7. Leistedt SJ, Linkowski P. Brain, networks, depression, and more. Eur Neuropsychopharmacol (2013) 23:55-62. doi:10.1016/j.euroneuro.2012.10.011

8. Gaiteri C, Ding Y, French B, Tseng GC, Sibille E. Beyond modules and hubs: the potential of gene coexpression networks for investigating molecular mechanisms of complex brain disorders. Genes Brain Behav (2013) 13(1):13-24. doi:10.1111/gbb.12106

9. Dwivedi Y. Evidence demonstrating role of microRNAs in the etiopathology of major depression. J Chem Neuroanat (2011) 42:142-56. doi:10.1016/ j.jchemneu.2011.04.002

10. Eacker SM, Dawson TM, Dawson VL. The interplay of microRNA and neuronal activity in health and disease. Front Cell Neurosci (2013) 7:136. doi:10.3389/ fncel.2013.00136

11. Smalheiser NR, Lugli G, Rizavi HS, Torvik VI, Turecki G, Dwivedi Y. MicroRNA expression is down-regulated and reorganized in prefrontal cortex of depressed suicide subjects. PLoS One (2012) 7:e33201. doi:10.1371/journal.pone.0033201

12. Smalheiser NR, Lugli G, Zhang H, Rizavi H, Cook EH, Dwivedi Y. Expression of microRNAs and other small RNAs in prefrontal cortex in schizophrenia, bipolar disorder and depressed subjects. PLoS One (2014) (in press).

13. Smalheiser NR, Lugli G, Rizavi HS, Zhang H, Torvik VI, Pandey GN, et al. MicroRNA expression in rat brain exposed to repeated inescapable shock: differential alterations in learned helplessness vs. non-learned helplessness. Int J Neuropsychopharmacol (2011) 14:1315-25. doi:10.1017/S1461145710001628

14. Shan G, Li Y, Zhang J, Li W, Szulwach KE, Duan R, et al. A small molecule enhances RNA interference and promotes microRNA processing. Nat Biotechnol (2008) 26:933-40. doi:10.1038/nbt.1481

15. Melo S, Villanueva A, Moutinho C, Davalos V, Spizzo R, Ivan C, et al. Small molecule enoxacin is a cancer-specific growth inhibitor that acts by enhancing TAR RNA-binding protein 2-mediated microRNA processing. Proc Natl Acad Sci U S A (2011) 108:4394-9. doi:10.1073/pnas.1014720108

16. Sousa E, Graça I, Baptista T, Vieira FQ, Palmeira C, Henrique R, et al. Enoxacin inhibits growth of prostate cancer cells and effectively restores microRNA processing. Epigenetics (2013) 8:548-58. doi:10.4161/epi.24519

17. Scheld WM. Quinolone therapy for infections of the central nervous system. Rev Infect Dis (1989) 11(Suppl 5):S1194-202. doi:10.1093/clinids/11.Supplement_ 5.S1194

18. Dwivedi Y, Mondal AC, Shukla PK, Rizavi HS, Lyons J. Altered protein kinase A in brain of learned helpless rats: effects of acute and repeated stress. Biol Psychiatry (2004) 56:30-40. doi:10.1016/j.biopsych.2004.03.018
19. Vollmayr B, Henn FA. Learned helplessness in the rat: improvements in validity and reliability. Brain Res Brain Res Protoc (2001) 8:1-7. doi:10.1016/S1385299X(01)00067-8

20. Dwivedi Y, Pandey GN. Elucidating biological risk factors in suicide: role of protein kinase A. Prog Neuropsychopharmacol Biol Psychiatry (2011) 35:831-41. doi:10.1016/j.pnpbp.2010.08.025.

21. Dwivedi Y, Mondal AC, Payappagoudar GV, Rizavi HS. Differential regulation of serotonin $(5 \mathrm{HT})_{2 \mathrm{~A}}$ receptor mRNA and protein levels after single and repeated stress in rat brain: role in learned helplessness behavior. Neuropharmacology (2005) 48:204-14. doi:10.1016/j.neuropharm.2004.10.004

22. Dwivedi Y, Mondal AC, Rizavi HS, Shukla PK, Pandey GN. Single and repeated stress-induced modulation of phospholipase $\mathrm{C}$ catalytic activity and expression: role in LH behavior. Neuropsychopharmacology (2005) 30:473-83. doi:10.1038/sj.npp.1300605

23. Chen H, Pandey GN, Dwivedi Y. Hippocampal cell proliferation regulation by repeated stress and antidepressants. Neuroreport (2006) 17:863-7. doi:10.1097/ 01.wnr.0000221827.03222.70

24. Lugli G, Torvik VI, Larson J, Smalheiser NR. Expression of microRNAs and their precursors in synaptic fractions of adult mouse forebrain. J Neurochem (2008) 106:650-61. doi:10.1111/j.1471-4159.2008.05413.x

25. Bhanot SK, Singh M, Chatterjee NR. The chemical and biological aspects of fluoroquinolones: reality and dreams. Curr Pharm Des (2001) 7:311-35. doi:10.2174/1381612013398059

26. Cheng LC, Pastrana E, Tavazoie M, Doetsch F. miR-124 regulates adult neurogenesis in the subventricular zone stem cell niche. Nat Neurosci (2009) 12:399-408. doi:10.1038/nn.2294

27. Feng C, Li J, Ruan J, Ding K. MicroRNA-125a inhibits cell growth by targeting glypican-4. Glycoconj J (2012) 29:503-11. doi:10.1007/s10719-012-9387-0

28. Le MT, Xie H, Zhou B, Chia PH, Rizk P, Um M, et al. MicroRNA-125b promotes neuronal differentiation in human cells by repressing multiple targets. Mol Cell Biol (2009) 29:5290-305. doi:10.1128/MCB.01694-08

29. Edbauer D, Neilson JR, Foster KA, Wang CF, Seeburg DP, Batterton MN, et al. Regulation of synaptic structure and function by FMRP-associated microRNAs miR-125b and miR-132. Neuron (2010) 65:373-84. doi:10.1016/j.neuron.2010. 01.005

30. Cimadamore F, Amador-Arjona A, Chen C, Huang CT, Terskikh AV. SOX2LIN28/let-7 pathway regulates proliferation and neurogenesis in neural precursors. Proc Natl Acad Sci U S A (2013) 110:E3017-26. doi:10.1073/pnas. 1220176110

31. Sempere LF, Freemantle S, Pitha-Rowe I, Moss E, Dmitrovsky E, Ambros V. Expression profiling of mammalian microRNAs uncovers a subset of brainexpressed microRNAs with possible roles in murine and human neuronal differentiation. Genome Biol (2004) 5:R13. doi:10.1186/gb-2004-5-3-r13

32. Ruiz CR, Shi J, Meffert MK. Transcript specificity in BDNF-regulated protein synthesis. Neuropharmacology (2014) 76 Pt C:657-63. doi:10.1016/j. neuropharm.2013.05.004

33. Wulczyn FG, Smirnova L, Rybak A, Brandt C, Kwidzinski E, Ninnemann O, et al. Post-transcriptional regulation of the let-7 microRNA during neural cell specification. FASEB J (2007) 21:415-26. doi:10.1096/fj.06-6130com

34. Wayman GA, Davare M, Ando H, Fortin D, Varlamova O, Cheng HY, et al. An activity-regulated microRNA controls dendritic plasticity by down-regulating p250GAP. Proc Natl Acad Sci U S A (2008) 105:9093-8. doi:10.1073/pnas. 0803072105

35. Vo N, Klein ME, Varlamova O, Keller DM, Yamamoto T, Goodman RH, et al. A cAMP-response element binding protein-induced microRNA regulates neuronal morphogenesis. Proc Natl Acad Sci U S A (2005) 102:16426-31. doi:10.1073/pnas.0508448102

36. Impey S, Davare M, Lasiek A, Fortin D, Ando H, Varlamova O, et al. An activity-induced microRNA controls dendritic spine formation by regulating Rac1-PAK signaling. Mol Cell Neurosci (2010) 43:146-56. doi:10.1016/j. mcn.2009.10.005

37. Wu J, Xie X. Comparative sequence analysis reveals an intricate network among REST, CREB and miRNA in mediating neuronal gene expression. Genome Biol (2006) 7:R85. doi:10.1186/gb-2006-7-9-r85

Conflict of Interest Statement: The University of Illinois at Chicago has filed a patent application for the use of enoxacin and related fluorquinolone compounds in the treatment of major depressive disorder and PTSD. 
Received: 28 October 2013; accepted: 12 January 2014; published online: 10 February 2014.

Citation: Smalheiser NR, Zhang H and Dwivedi Y (2014) Enoxacin elevates microRNA levels in rat frontal cortex and prevents learned helplessness. Front. Psychiatry 5:6. doi: 10.3389/fpsyt.2014.00006

This article was submitted to Neurogenomics, a section of the journal Frontiers in Psychiatry.
Copyright (C) 2014 Smalheiser, Zhang and Dwivedi. This is an open-access article distributed under the terms of the Creative Commons Attribution License (CC BY). The use, distribution or reproduction in other forums is permitted, provided the original author(s) or licensor are credited and that the original publication in this journal is cited, in accordance with accepted academic practice. No use, distribution or reproduction is permitted which does not comply with these terms. 


\section{APPENDIX}

Table A1 | Confirmation experiment in a separate group of rats showing escape latency of individual rats when given no shock or inescapable shock and simultaneously treated with saline or enoxacin (10 or $25 \mathrm{mg} / \mathrm{kg}$ ).

\begin{tabular}{|c|c|c|c|}
\hline Shock or no shock ${ }^{a}$ & Treatment & $\begin{array}{l}\text { Escape } \\
\text { latency (s) }\end{array}$ & $\begin{array}{l}\text { Response to } \\
\text { shock }^{\text {b }}\end{array}$ \\
\hline Sham (no shock) & Saline & 9.684 & \\
\hline Sham (no shock) & Saline & 5.324 & \\
\hline Sham (no shock) & Saline & 9.216 & \\
\hline Sham (no shock) & Saline & 3.496 & \\
\hline Sham (no shock) & Saline & 3.732 & \\
\hline Sham (no shock) & Saline & 4.152 & \\
\hline Sham (no shock) & Saline & 3.19 & \\
\hline Sham (no shock) & Saline & 6.36 & \\
\hline Shock & Enoxacin $(10 \mathrm{mg} / \mathrm{kg})$ & 4.316 & $\mathrm{NLH}$ \\
\hline Shock & Enoxacin $(10 \mathrm{mg} / \mathrm{kg})$ & 3.952 & $\mathrm{NLH}$ \\
\hline Shock & Enoxacin $(10 \mathrm{mg} / \mathrm{kg})$ & 4.312 & $\mathrm{NLH}$ \\
\hline Shock & Enoxacin $(10 \mathrm{mg} / \mathrm{kg})$ & 25.776 & $\mathrm{LH}$ \\
\hline Shock & Enoxacin $(10 \mathrm{mg} / \mathrm{kg})$ & 9.656 & $\mathrm{NLH}$ \\
\hline Shock & Enoxacin $(10$ mg/kg) & 9.26 & $\mathrm{NLH}$ \\
\hline Shock & Enoxacin $(10 \mathrm{mg} / \mathrm{kg})$ & 26.968 & $\mathrm{LH}$ \\
\hline Shock & Enoxacin $(10$ mg/kg) & 6.872 & $\mathrm{NLH}$ \\
\hline Shock & Enoxacin $(10 \mathrm{mg} / \mathrm{kg})$ & 5.944 & $\mathrm{NLH}$ \\
\hline Shock & Enoxacin $(25$ mg/kg) & 3.776 & $\mathrm{NLH}$ \\
\hline Shock & Enoxacin $(25 \mathrm{mg} / \mathrm{kg})$ & 26.3 & $\mathrm{LH}$ \\
\hline Shock & Enoxacin $(25 \mathrm{mg} / \mathrm{kg})$ & 7.088 & $\mathrm{NLH}$ \\
\hline Shock & Enoxacin $(25 \mathrm{mg} / \mathrm{kg})$ & 2.512 & $\mathrm{NLH}$ \\
\hline Shock & Enoxacin $(25$ mg/kg) & 4.444 & NLH \\
\hline Shock & Enoxacin $(25 \mathrm{mg} / \mathrm{kg})$ & 3.244 & $\mathrm{NLH}$ \\
\hline Shock & Enoxacin $(25 \mathrm{mg} / \mathrm{kg})$ & 29.476 & $\mathrm{LH}$ \\
\hline Shock & Enoxacin $(25$ mg/kg) & 13.924 & $\mathrm{NLH}$ \\
\hline Shock & Enoxacin $(25 \mathrm{mg} / \mathrm{kg})$ & 8.632 & $\mathrm{NLH}$ \\
\hline
\end{tabular}

a Sham rats were given no shock on day 6 but were tested for escape latency on day 7.

${ }^{b}$ For rats exposed to shock, escape latency $<20 s=$ non-learned helpless $(N L H) ; \geq 20 s=$ learned helpless $(L H)$. 